\title{
Cutaneous Endometriosis: A Differential Diagnosis of Umbilical Nodule
}

\section{Endometriose Cutânea: Um Diagnóstico Diferencial de Nódulo Umbilical}

\author{
Mariana BATISTA $\triangle^{1}$, Francisca ALVES ${ }^{1}$, José CARDOSO ${ }^{1}$, Margarida GONÇALO ${ }^{1,2}$ \\ Acta Med Port 2020 Apr;33(4):282-284 - https://doi.org/10.20344/amp.10966
}

\section{ABSTRACT}

Endometriosis is a chronic disorder characterized by the presence of ectopic functional endometrial tissue outside the uterine cavity and which affects about $10 \%$ of all women of reproductive age. Cutaneous endometriosis, usually localized in the abdominal wall, is a rare entity. We report the case of a nulliparous woman with an acute painful umbilical nodule that slowly increased in size during the days prior to observation. The lesion was surrounded by a painful periumbilical subcutaneous plaque. The patient denied associated constitutional symptoms and reported two similar episodes in the previous two years. A skin biopsy was performed, and histopathologic examination was consistent with the diagnosis of endometriosis. This article reviews this disease particularly rare in nulliparous and highlights the importance of recognizing this clinical presentation of endometriosis due to its frequent association with pelvic disease that can lead to reduced fertility.

Keywords: Endometriosis; Skin Diseases/diagnosis; Umbilicus

\section{RESUMO}

A endometriose é uma doença crónica caracterizada pela presença de endométrio funcional fora da cavidade uterina que afeta aproximadamente $10 \%$ das mulheres em idade reprodutiva. A endometriose cutânea com localização habitual na parede abdominal é uma manifestação rara da doença. Apresenta-se o caso de uma mulher jovem nulípara com um nódulo umbilical doloroso e de crescimento recente com placa dolorosa subcutânea periumbilical, sem outra sintomatologia associada. A anamnese revelou dois episódios semeIhantes nos últimos dois anos. Foi realizada biópsia cutânea da lesão e o exame anatomopatológico foi compatível com endometriose. Os autores fazem uma revisão desta entidade clínica e realçam a importância do reconhecimento desta forma de apresentação, rara em nulíparas, dada a associação frequente a focos de endometriose noutras localizações e que podem condicionar um baixo nível de fertilidade.

Palavras-chave: Doenças da Pele/diagnóstico; Endometriose; Umbigo

\section{INTRODUCTION}

Endometriosis is a benign, estrogen-dependent, chronic disorder characterized by the presence of ectopic functional endometrial tissue outside the uterine cavity, usually in other adjacent pelvic organs. ${ }^{1}$ This condition affects $10 \%-$ $15 \%$ of all women during reproductive age ( $18-49$ years). ${ }^{2}$ The most common sites of implantation are the ovaries and fallopian tubes but it can develop in virtually any organ, and has been described in sites such as the lung, liver, pleura, brain and skin. ${ }^{3}$ Ectopic endometrial tissue in the skin, usually in the abdominal wall, accounts for less than $1 \%$ of ectopic endometriosis. ${ }^{4}$

\section{CASE REPORT}

A nulliparous 24-year-old woman presented to our dermatology department complaining of an acute painful umbilical nodule that slowly increased in size during the days prior to observation. Patient denied associated constitutional symptoms. On physical examination she had a tender bluish-purple nodule in the umbilicus, approximately $1 \mathrm{~cm}$ in diameter (Fig. 1) and a painful periumbilical subcutaneous infiltration. The patient reported two similar episodes in the previous two years. During these outbreaks the lesion did not improve on topical or oral antibiotics. She reported no further symptoms and said the morphology of the umbilicus between the episodes of acute exacerbation was normal. Her medical and surgical history was unremarkable. The patient denied pelvic/abdominal pain, dysmenorrhea or dyspareunia. She had been taking an oral contraceptive pill for several years (cyproterone acetate $2 \mathrm{mg} /$ ethinylestradiol $0.035 \mathrm{mg}$ ), had regular menstrual cycles and did not notice any relation of the cutaneous symptoms with menstruation. Histopathologic examination of an incisional skin biopsy stained with hematoxylin-eosin showed a cystic cavity lined by a single layer of monomorphous cuboidal cells, without atypia, surrounded by a cellular myxoid stroma with focal hemorrhage and areas of hemosiderin deposition, consistent with umbilical endometriosis (Fig. 2). The patient was referred to gynecology where further workup was unrevealing, namely abdominopelvic and transvaginal ultrasounds, and a different type of contraceptive pill was advised (dienogest $2 \mathrm{mg} /$ ethinylestradiol $0.03 \mathrm{mg}$ ). Since other potential ectopic endometrial foci were excluded, the diagnosis of primary cutaneous endometriosis was established. At five months' follow-up there was no sign of local disease and umbilicus had a normal appearance so additional procedures were not performed.

\footnotetext{
1. Department of Dermatology. Centro Hospitalar e Universitário de Coimbra. Coimbra. Portugal.

2. Department of Dermatology. Faculty of Medicine. University of Coimbra. Coimbra. Portugal.

$\bowtie$ Autor correspondente: Mariana Batista. sousabatistamariana@gmail.com

Recebido: 18 de junho de 2018 - Aceite: 22 de novembro de 2018 | Copyright @ Ordem dos Médicos 2020
} 


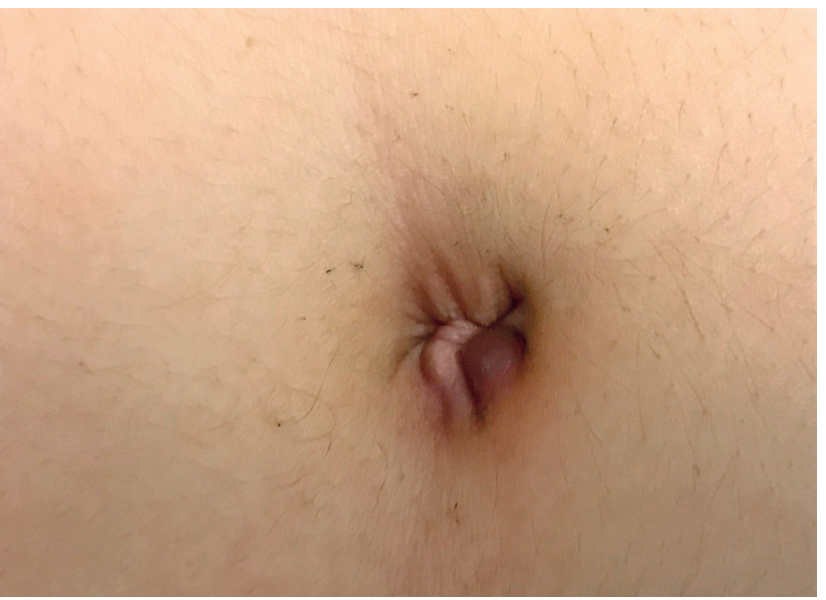

Figure 1 - Cutaneous endometriosis - clinical findings: umbilical purplish nodule, with no signs of bleeding, crusting or cutaneous inflammatory signs

\section{DISCUSSION}

Cutaneous endometriosis, a rare entity, refers to the presence of implants of endometrial tissue in the abdominal wall. Depending on its origin, it is divided into primary and secondary. Secondary cutaneous endometriosis, also called iatrogenic endometriosis, is associated with previous surgery, ${ }^{5}$ mostly a caesarean section. ${ }^{6}$ Primary cutaneous endometriosis, also known as spontaneous endometriosis, has no relationship with surgical procedures.

Umbilical endometriosis, due to the high frequency in that location, and Villar's nodule, with reference to the physician who first described it in $1886,{ }^{7}$ are other terms for the disease. Typical clinical presentation of primary umbilical endometriosis is a discrete bluish- purple nodule in the umbilicus which becomes swollen, painful and bleeds concomitantly with menstruation. However, the clinical picture can vary considerably, for example showing no relation between pain episodes and menstruation cycles, which makes the diagnosis unsuspected, like in our patient. The origin of primary cutaneous endometriosis is still unknown. Suggested possible theories are composed of endometrial cells migrating to the umbilicus through the abdomen or the lymphatic system, and/ or remnants of embryonic cells in the umbilical fold. ${ }^{8}$ Also, it is possible that the umbilicus acts as a physiological scar with a predilection for ectopic endometrial implants. ${ }^{9}$

Histopathology is the gold standard to confirm the diagnosis and allows to rule out malignancy. ${ }^{10}$ The differential diagnosis of umbilical endometriosis is very wide, including benign and malignant conditions such as omphalitis, keloids, hernias, melanocytic nevi, abscesses, anomalies of the urachus, metastasis of an intra-abdominal neoplasm (Sister Mary Joseph nodule), melanoma, among others.

Medical treatment is based on contraceptive hormones with some authors reporting success in relieving symptoms and reducing the size of the endometrial nodule. ${ }^{11,12} \mathrm{How}-$ ever the treatment of choice is complete surgical excision, with the surgical technique depending on the extension of the lesion. ${ }^{13}$ Recurrence rate after surgery is considered low $(4 \%-11 \%))^{1,10}$ Reported prevalence rates of associated pelvic endometriosis range from $15 \%$ to $25 \%,{ }^{14,15}$ higher than in the general population. Therefore, additional workup is recommended to rule out associated endometriosis, namely a gynecological examination, including pelvic and transvaginal ultrasound.

Diagnosis of primary cutaneous endometriosis can be challenging due to its rarity and lack of knowledge about the disease. Even though it is an uncommon entity, it should be remembered by dermatologists and other physicians when evaluating abdominal masses in reproductive women. This equally applies to patients with no previous history of abdominal surgery or those who deny a relationship between symptoms and the menstrual cycle, like in our patient. Histology is the key to an accurate diagnosis.

\section{PROTECTION OF HUMANS AND ANIMALS}

The authors declare that the procedures were followed according to the regulations established by the Clinical Research and Ethics Committee and to the Helsinki Declaration of the World Medical Association.
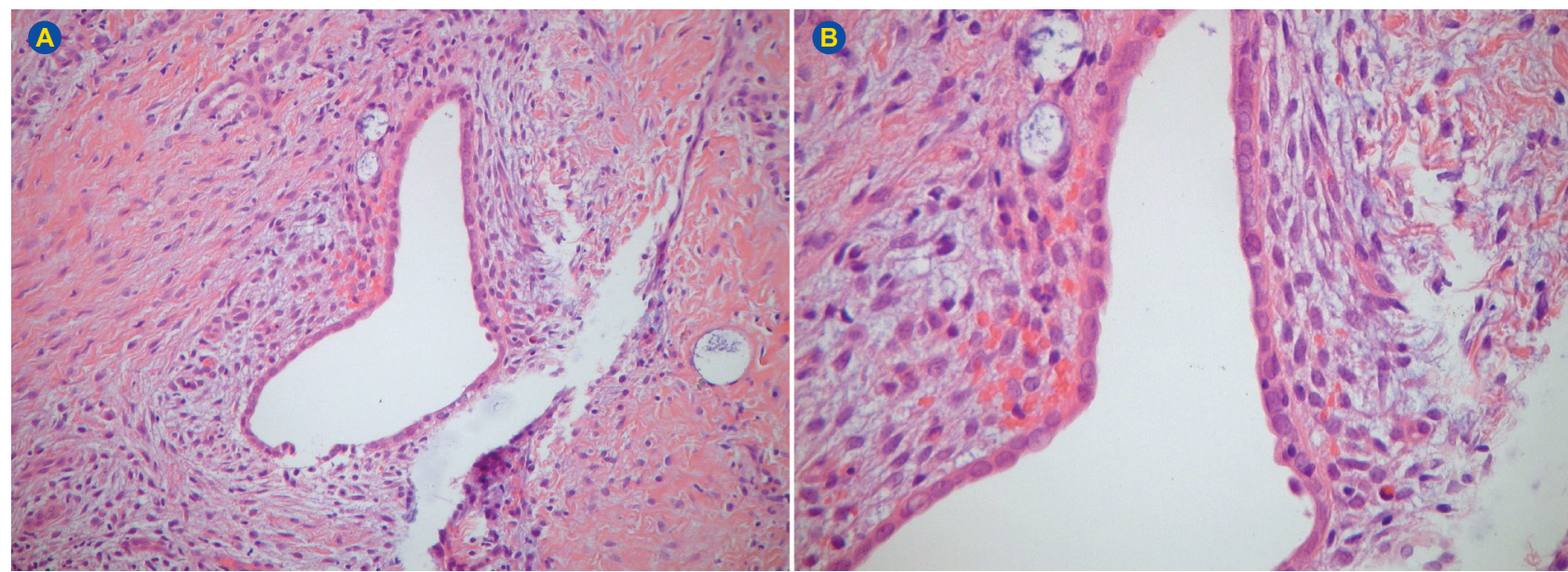

Figure 2 - Cutaneous endometriosis - microscopic features: (A) Cystic cavity lined by monomorphous cuboidal cells. (B) Cellular myxoid stroma with focal hemorrhage. Haematoxylin and eosin, original magnification (A) x 200, (B) $\times 400$. 


\section{DATA CONFIDENTIALITY}

The authors declare having followed the protocols in use at their working center regarding patients' data publication.

\section{INFORMED CONSENT}

Obtained.

\section{REFERENCES}

1. Boesgaard-Kjer D, Boesgaard-Kjer D, Kjer JJ. Primary umbilical endometriosis (PUE). Eur J Obstet Gynecol Reprod Biol. 2017;209:445 .

2. Fuldeore MJ, Soliman AM. Prevalence and symptomatic burden of diagnosed endometriosis in the United States: national estimates from a cross-sectional survey of 59,411 women. Gynecol Obstet Invest. 2017;82:453-61.

3. Kyamidis K, Lora V, Kanitakis J. Spontaneous cutaneous umbilical endometriosis: report of a new case with immunohistochemical study and literature review. Dermatol Online J. 2011;17:5

4. Ghosh A, Das S. Primary umbilical endometriosis: a case report and review of literature. Arch Gynecol Obstet. 2014;290:807-9.

5. Ecker AM, Donnellan NM, Shepherd JP, Lee TT. Abdominal wall endometriosis: 12 years of experience at a large academic institution. Am J Obstet Gynecol. 2014;211:363.e1-5.

6. Lopez-Soto A, Sanchez-Zapata MI, Martinez-Cendan JP, Ortiz Reina S, Bernal Mañas CM, Remezal Solano M. Cutaneous endometriosis: presentation of 33 cases and literature review. Eur J Obstet Gynecol Reprod Biol. 2018;221:58-63.

7. Pariza G, Mavrodin Cl. Primary umbilical endometriosis (Villar's nodule) - case study, literature revision. Chirurgia. 2014;109:546-9.

8. Victory R, Diamond MP, Johns DA. Villar's nodule: a case report and

\section{CONFLICTS OF INTEREST}

All authors report no conflict of interest.

\section{FUNDING SOURCES}

The authors declare that there were no external sources of study for the performance of this article.

systematic literature review of endometriosis externa of the umbilicus. J Minim Invasive Gynecol. 2007;14:23-32.

9. Van den Nouland D, Kaur M. Primary umbilical endometriosis: a case report. Facts Views Vis Obgyn. 2017;9:115-9.

10. Stojanovic $M$, Brasanac $D$, Stojicic $M$. Cutaneous inguinal scar endosalpingiosis and endometriosis: case report with review of literature. Am J Dermatopathol. 2013;35:254-60.

11. Rosina P, Pugliarello S, Colato C, Girolomoni G. Endometriosis of umbilical cicatrix: case report and review of the literature. Acta Dermatovenerol Croat. 2008;16:218-21.

12. Bagade PV, Giurguis MM. Menstruating from the umbilicus as a rare case of primary umbilicalendometriosis: a case report. J Med Case Rep. 2009;3:9326.

13. Heller DS. Lesions of the umbilicus: what the minimally invasive gynecologic surgeon needs to know about the belly button. J Minim Invasive Gynecol. 2012;19:680-3.

14. Dadhwal V, Gupta B, Dasgupta C, Shende U, Deka D. Primary umbilical endometriosis: a rare entity. Arch Gynecol Obstet. 2011;283:119-20.

15. Zhai J. Spontaneous cutaneous endometriosis in the mons pubis region: a case report diagnosed by fine-needle aspiration biopsy. Diagn Cytopathol. 2014;42:615-8. 